\title{
STATUS KESEHATAN BAYI DAN SIKAP PETUGAS TERHADAP PELAKSANAAN INISIASI MENYUSU DINI PADA IBU BERSALIN
}

\author{
Nurmaliza \\ Program Studi D-III Kebidanan Universitas Abdurrab \\ J1. Riau Ujung 73, Riau 28292 Indonesia \\ email : nurmaliza@univrab.ac.id
}

\begin{abstract}
Early breastfeeding initiation (IMD) is a natural process of returning a baby to breastfeed, by allowing the baby to seek and suck his own milk. Survey of WHO through more than 3000 post-partum maternal in each states, show that the maternals which operate IMD or giving of the breastfood minimally a hour after the baby is born only about 38,33\%. IMD scope in Indonesia is still low, those are 29,3\% in 2010 experiences the decrease to be 34,5\% in 2013. The IMD practice proporsion in a hour early birth is $43,9 \%$, while IMD in a early day is $61,5 \%$. The research aims to determine the factors which relate with the early breastfood initiation operation, that is the medical worker's attitude and baby health status. The research is analytic quantitaive with design type is cross sectional. The data analysist was operated as univariate and bivariate Population is all post-partum maternals which was in he maternity hospital of society health center working area of Payung Sekaki of Pekanbaru city in 2015 with 220 people. The used sampling method is proportional sampling. The result of bivariate analysis showed that there was correlation between infant health status and health officer attitude toward IMD implementation with p-value $<0.05(<0.001$ $<0.05)$. Suggested on the maternals and medical workers to operate and support the early breastfood initation program, then decreasing the nutrient as long as the pragnance to avoid abnormality or disturbion on the baby.
\end{abstract}

Key words: Early Breastfood Initation Operation, Society Healh Center Of Payung Sekaki

\section{PENDAHULUAN}

Pelaksanaan Inisiasi Menyusu Dini (IMD) adalah kegiatan membiarkan bayi menyusu sendiri pada ibunya segera setelah lahir setidaknya 1 jam bahkan lebih sampai bayi dapat menyusu sendiri. IMD mempunyai manfaat yang sangat besar untuk bayi maupun ibu yang baru melahirkan. IMD juga dapat meningkatkan daya tahan tubuh bayi sehingga mengurangi resiko kematian bayi baru lahir (Roesli, 2013).

Berdasarkan survei dari World Health Organization (WHO) terhadap lebih dari 3000 ibu pasca persalinan di beberapa negara, menunjukkan bahwa ibu yang melakukan IMD atau pemberian ASI minimal satu jam setelah bayi lahir hanya sekitar 38,33\%. Cakupan IMD di Indonesia masih rendah yaitu 29,3\% di Tahun 2010 mengalami kenaikan menjadi $34,5 \%$ di tahun 2013 (Kemenkes, 2013).

Beberapa penelitian dan survei menyatakan bahwa manfaat dan keuntungan dari IMD baik bagi ibu, bagi bayi, juga bagi keluarga dan masyarakat, namun ironisnya cakupan praktik IMD masih sangat rendah (Depkes RI, 2002).

Persentase pemberian ASI eksklusif dalam 24 jam terakhir dan tanpa riwayat diberikan makanan dan minuman selain ASI pada umur 6 bulan sebesar 30,2 persen. Inisiasi menyusu dini kurang dari satu jam setelah bayi lahir adalah 34,5 persen, tertinggi di Nusa Tenggara Barat, yaitu sebesar 52,9 persen dan terendah di Papua Barat $(21,7 \%)$ 
(Kemenkes, 2013).

Berdasarkan survey awal yang peneliti lakukan di wilayah Puskesmas Payung Sekaki Kota Pekanbaru, hanya 2 Rumah Bersalin (RB) yang melakukan praktek IMD. Hal ini dikarenakan kurangnya pemahaman ibu dan petugas kesehatan tentang IMD, dan kemungkinan ada hal-hal lain yang menjadi alasan tidak terlaksananya IMD. Hal ini menunjukkan bahwa pentingnnya peran dari petugas kesehatan, pengetahuan dari ibu untuk terlaksananya IMD. Faktor lain yang berperan dalam pelaksanaan IMD adalah status kesehatan bayi. Berdasarkan hasil survey di atas maka peneliti tertarik untuk meneliti dengan tujuan untuk mengetahui "hubungan status kesehatan bayi dan sikap petugas terhadap pelaksanaan (IMD) pada ibu bersalin.

\section{METODE PENELITIAN}

Penelitian ini bersifat kuantitatif analitik dengan menggunakan jenis desain Cross Sectional Study (Lapau, 2012). Penelitian ini dilakukan di wilayah kerja Puskesmas Payung Sekaki Kota Pekanbaru pada bulan Juni 2015. Sampel dalam penelitian ini adalah ibu bersalin yang berada di wilayah kerja Puskesmas Payung Sekaki sebanyak 220 orang. Variabel bebas pada penelitian ini adalah status kesehatan bayi dan sikap petugas, dan variabel terikat yaitu pelaksanaan IMD. Pengambilan sampel dilakukan dengan proportional sampling. Pengumpulan data dilakukan dengan menggunakan kuesioner, analisa data yang digunakan adalah univariat dan bivariat dengan uji chi-square.

\section{HASIL DAN PEMBAHASAN}

\section{a. Analisis Univariat Variabel Dependen}

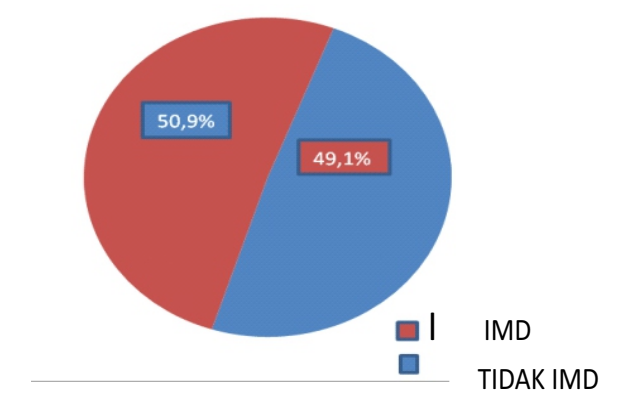

Gambar 1. Proporsi Pelaksanaan IMD Pada Ibu Bersalin Di Wilayah Kerja Puskesmas Payung Sekaki

Berdasarkan analisis univariat pada Gambar 1 menunjukkan bahwa dari 220 ibu bersalin yang tidak melaksanakan IMD sebanyak 108 orang $(49,1 \%)$ dan yang melaksanakan IMD sebanyak 112 orang $(50,9 \%)$.

\section{b. Analisa Univariat Variabel Dependen}

Pada tabel 1 menunjukkan bahwa dari $220 \mathrm{ibu}$ bersalin didapatkan hasil, sikap petugas kesehatan yang negatif sebanyak 48,6\% dan ada gangguan kesehatan pada bayi sebanyak $35,0 \%$.

Tabel 1 Distribusi variabel independen tentang pelaksanaan IMD pada ibu bersalin

\begin{tabular}{lllc}
\hline \multirow{2}{*}{ No } & Variabel Independen & \multicolumn{2}{c}{ Jumlah } \\
\cline { 3 - 4 } & & N & \multicolumn{2}{c}{$\%$} \\
\hline 1. & Sikap Petugas Kesehatan & & \\
& -Negatif & 107 & 48,6 \\
& -Positif & 113 & 51,4 \\
2. & Status Kesehatan Bayi & & \\
& -Ada gangguan & 77 & 35,0 \\
& -Tidak ada gangguan & 143 & 65,0 \\
\hline
\end{tabular}




\section{c. Analisis Bivariat}

Tabel 7. Hubungan status kesehatan bayi dan siakp petugas kesehatan terhadap pelaksanaan IMD pada ibu bersalin

\begin{tabular}{|c|c|c|c|c|c|c|c|c|}
\hline \multirow{3}{*}{$\begin{array}{l}\text { Variabel } \\
\text { Indepden }\end{array}$} & \multicolumn{4}{|c|}{ Pelaksanaan IMD } & \multicolumn{2}{|c|}{ Jumlah } & \multirow{3}{*}{$\begin{array}{l}P \text { - } \\
\text { value }\end{array}$} & \multirow{3}{*}{$\begin{array}{c}\text { POR } \\
(95 \% \\
\text { CI) }\end{array}$} \\
\hline & \multicolumn{2}{|c|}{ Tidak } & \multicolumn{2}{|c|}{ Iya } & & & & \\
\hline & $\mathrm{n}$ & $(\%)$ & $\mathrm{n}$ & $(\%)$ & $\mathrm{n}$ & $(\%)$ & & \\
\hline
\end{tabular}

\section{Sikap Petugas}

Kesehatan

Negatif

Positif

$\begin{array}{lll}78 & (72,9) \quad 29\end{array}$

$30 \quad(26,5) \quad 83$

$\begin{array}{llll}(27,1) & 107 & (100) & 0,000 \\ (73,5) & 113 & (100) & \end{array}$

\section{Status Kesehatan}

\section{Bayi}

\begin{tabular}{lcccccccc}
$\begin{array}{l}\text { Ada gangguan } \\
\text { Tidak ada } \\
\text { gangguan }\end{array}$ & 68 & $(88,3)$ & 9 & $(11,7)$ & 77 & $(100)$ & 0,000 & $\begin{array}{c}19,456 \\
(8,872-\end{array}$ \\
\hline
\end{tabular}

Pada tabel 2 dapat dilihat bahwa sikap petugas yang negatif cenderung tidak melaksanaakan IMD sebanyak 27,1\%, bila sikap petugas yang positif cenderung malaksanakan IMD sebanyak 73,5\%. Sedangkan status kesehatan bayi bila ada gangguan cenderung tidak melaksanakan IMD sebanyak $11,7 \%$ dan bila status kesehatan bayi tanpa ada gangguan (normal) cenderung melakuakan praktik IMD sebanyak $72 \%$. Oleh karena itu jika petugas kesehatan bersikap negatif 7 kali lebih berisiko tidak melakukan praktik IMD dengan O.R 7,441. Sedangkan status kesehatan bila ada gangguan 19 lebih berisiko tidak malakukan praktik IMD dengan O.R 19,456.

Bila status kesehatan bayi normal (tidak ada gangguan) maka IMD dapat dilaksanakan, dan apabila bayi mengalami gangguan maka IMD tidak dapat dilaksanakan. Pengukuran status kesehatan bayi dilakukan setelah ibu melahirkan. Dengan adanya gangguan kesehatan pada bayi (tidak normal) maka dapat memberikan gambaran kecenderungan berisiko untuk tidak bisa dilaksanakannya IMD.

Kesulitan pelaksanaan inisiasi menyusu dini juga disebabkan karena kondisi bayi. Faktor utama tidak dilakukan praktik IMD adalah dikarenakan APGAR Skor $\leq 7$, bayi tidak langsung menangis saat segera setelah lahir, tidak bergerak dengan aktif, lemahnya pergerakan nadi, dan bernafas tidak lancar atau megap-megap. Anak yang lahir sebelum waktunya (premature) atau lahir dengan berat badan yang sangat rendah dan kondisi tubuh yang masih lemah apabila harus menghisap ASI. 
Selain itu pada waktu anak sakit juga akan sulit menyusu. Berbagai macam cacat bibir juga dapat menimbulkan kesulitan pada bayi untuk menyusu..

Begitu juga dengan sikap petugas yang positif selalu memberikan pendidikan kesehatan serta mendukung dalam berbagai program kesehatan salah satunya adalah pelaksanaan IMD. Karena itu, sangat penting sekali setiap petugas kesehatan dari pihak rumah sakit atau rumah bersalin mengikuti pelatihan ataupun seminar tentang IMD. Atas dasar ini direkomendasikan supaya ibu selalu memiliki sikap positif terhadap pelaksanaan IMD, meningkatkan lagi pengetahuan dengan mencari informasi tentang kesehatan baik melalui media massa ataupun media elektronik.

Inisiasi Menyusu Dini (early initiation) atau permulaan menyusu dini adalah bayi mulai menyusu sendiri segera setelah lahir. Asalkan dibiarkan kontak kulit bayi dengan kulit ibunya, setidaknya satu jam segera setelah lahir. Cara bayi melakukan inisiasi menyusu dini ini dinamakan the breast crawl atau merangkak mencari payudara (Roesli, 2008). IMD adalah perilaku pencarian puting payudara ibu sesaat setelah bayi lahir (Prasetyono, 2009). Anak yang dapat menyusui dini dapat mudah sekali menyusu kemudian, sehingga kegagalan menyusui akan jauh sekali berkurang. Selain mendapatkan kolostrum yang bermanfaat untuk bayi, pemberian ASI ekslusif akan menurunkan kematian (Sartika, 2009).

\section{SIMPULAN DAN SARAN}

\section{a. Simpulan}

Dari 220 responden sebagian besar responden melaksanakan IMD sebanyak 112 orang $(50,9 \%)$, sikap petugas kesehatan positif sebanyak 113 orang $(51,4 \%)$, tidak ada gangguan (normal) sebanyak 143 orang (65\%) dan hasil uji chi-square nilai Pvalue $<0,05(<0,001<0,05)$ terdapat hubungan antara status kesehatan bayi dan sikap petugas kesehatan terhadap pelaksanaan IMD pada ibu bersalin

\section{b. Saran}

Diupayakan bagi tenaga kesehatan untuk meningkatkan kegiatan konseling, lebih gencar dalam promosi dan memotivasi ibu dalam pelaksanaan IMD, serta mengikuti pelatihan atau seminar tentang kesehatan khususnya IMD, bertanggung jawab sebagai unit pelaksana teknis pelayanan kesehatan masyarakat untuk memberikan penyuluhan dan melaksanakan atau menjalankan program pemerintah.

\section{DAFTAR PUSTAKA}

Depkes RI, 2002, Profil Kesehatan Indonesia, Jakarta: Depkes.

Lapau Buchari, 2012, Metode Penelitian Kesehatan, Jakarta: Yayasan Pustaka Obor Indonesia

Prasetyono, Dwi Sunar. 2009. Buku Pintar ASI Eksklusif. Jakarta : Diva Pres 2008, dikutip dari www. republika newroom.com 
Kemenkes RI, 2013, Riset Kesehatan Dasar, Badan Penelitian Pengembangan Kesehatan. Bakti Husada. dikutip dari www.jurnalbogor.com

Roesli Utami, 2008, Inisiasi Menyusu Dini dan ASI Esklusif, Jakarta: Pustaka

Roesli Utami SpA, MBA, IBCLC, 2013, Inisiasi Menyusu Dini Untuk Awali ASI Eksklusif, 16 September

Sartika Dewi, S. Pd, M. Si, Sosialisasi ASI Eksklusif dan IMD, 17 January 2009 